\title{
During the Pandemic Period, the Determination and Relationship of Curling Athletes with Their Task and Ego Orientation and Personality Situations and the Remote Support Situations They Received
}

\author{
Alaeddinoglu Vahdet (Corresponding Author) \\ Horasan Vocational High School \\ Ataturk University, Istanbul, Turkey \\ E-mail: v.alaeddinoglu@atauni.edu.tr
}

Received: September 13, 2020

Accepted: October 19, 2020

Published: November 2, 2020

doi:10.5296/jei.v6i2.17692

URL: https://doi.org/10.5296/jei.v6i2.17692

\begin{abstract}
The aim of this study was to evaluate the personality, ego and task orientation of elite Curling athletes in the pandemic era, and the distance education support they received. Research questions were produced on the Google Forms and mailed to the athletes. Curling Super League, 1st League, and 2nd League players consisted of a total of 89 athletes were included. Explanatory information was given for the motivation of the athletes. The questionnaire consists of four stages. Explanatory information is provided for the motivation of the athletes. Demographic features are included in the 1st stage. It consists of 14 questions. At the 2nd stage, the "Task and Ego Orientation Scale in Sports" consisted of 13 items, seven of which are task orientation, and six of which are ego orientation. Those who respond to the scale participate in each article according to the evaluation system of 5. At the 3rd stage, the Eysenck Personality Scale, adapted by Karanci, consists of 23 questions in total. Questions were asked in the form of yes or no. In the final stage, there was a scale developed to evaluate the mental and physical support that Curling athletes received during the pandemic era. Athletes were expected to answer these questions. It was analyzed with SPSS 22.00 statistical program. By looking at the level of interaction between the questions, Pearson Correlation techniques were used. To test the construct validity of the scale, principal components factor analysis using Oblimin rotation method was used, item-total correlations were examined, and Cronbach's Alpha coefficients were examined to determine internal consistency. The Cronbach Alpha number was found to be .085 . Furthermore, interpretations with a value of 0.05 were made as to the error value. As a
\end{abstract}


result, it has been observed that there is a positive correlation between Ego and Task orientation, personality and Sport perception and orientation and distance education support. It has been observed that there is a negative relationship between the lying sub-dimension of personality and neuroticism. It has been observed that there is a positive relationship between the task and ego orientation dimension in sports and the orientation to perceive sports and distance education support. It has been observed that Curling athletes had good mental and physical preparation periods during this period. It was also concluded that the implications of the tests carried out should be monitored on other sports branches.

Keywords: Ego and Task Orientation in Sport, Eysenck Personality Questionnaire, Mental support, Distance education, Curling

\section{Introduction}

Some of the biggest expectations of athletes, coaches, and administrators in a sport is that the athletes to be always ready during and out of the competition period (Gunduz, Sevim, \& Hazir, 2002). The success or failure of athletes depends on different factors (Dorak \& Tiryaki, 1991). The athletes' training programs, level of condition, the conditions of the opposing teams, the conditions of the field, mental factors and their reactions to those factors (Kalkavan, Pinar, Kılınç, \& Yüksel, 2005). The athletes' personality and ego task orientations are also other influencing factors (Kaynar, Seyhan, \& Bilici, 2018).

Goal-oriented and target-oriented athletes train for a higher-level challenge when they meet these expected target (Toros, 2004). The athletes perform the entire season in three cycles under normal conditions. Those are generally; May be graded as Preseason, Season of Competition, and Season of Rest. Sometimes because of the emergence of extraordinary conditions, people may experience long-term separations due to a season of forced rest (Akyuz, 2017). The athletes fall into a passive position during that time. Today, these conditions are felt and there is a long-term break from all tournaments and preparation (WHO, 2020). The Covid-19 outbreak, which first occurred in Wuhan, China in December 2019, was found in about 3.5 million people worldwide and is described as an infectious and lethal disease that can be found in all countries and regions of the world. World Health Organization turned this epidemic a pandemic disease with the death about 720 thousand people worldwide (WHO, 2020). In this context, the Turkish Ministry of Health, the Ministry of the Interior and the Ministry of Sports decided to stop all the sport organizations in the country with a circular and the athletes continued their education at home on 16.3.2020 (T.R. Ministry of Interior, 2020). During this period, in Turkey, as in all countries, many sports organizations were canceled and athletes were asked to continue training in home training programs. For the athletes who could not do active sports, training programs were prepared to be done at home by both the federation and their trainers after this epidemic, many great changes took place in the world. All the country's ministries have been trying to adapt these changes, particularly in the field of education.

Many countries' and our country's main agenda item is the COVID-19 virus, and its effects. The COVID-19 virus, known as Corona, causes tough times for all people over the world, people has to name the pandemic era as two stages. Because, with the spread of this disease, 
changes have begun to appear in almost all points of life. For example, the social distance rule applied in daily and social life, the closure of schools, the transition of universities to distance education programs, the postponement of many sport organizations, and even the postponement of the International Olympic Committee is some of these changes. In this context, Turkey Curling Federation has also been forced to cancel the events (Turkish Curling Federation, 2020).

Personality traits are all of the individual and social responses that are manifested by an individual's anxiety, fear, emotional approach, logical approach, low self-esteem, and irrational approach in the face of a certain emotion and behavior. While the Eysenck personality theory addressed neuroticism-stability and extroversion-introversion dimensions when it was first put forward, the psychoticism dimension was added later during the development phase. While the extroversion dimension represents the social and impulsive sides of the individual, the stability dimension represents the emotional consistency and overreaction side. In the psychoticism dimension, the individual is cold, distant, insecure, and lacks empathy and shows insensitivity to other people (Karanci, Dirik, \& Yorulmaz, 2007).

In sports organizations, the personality traits stated above are among the most important factors that affect the motivation of both the team and the individual during training, exercise, or competition. Success or failure depend on how these personality traits affect task-ego orientation. Studies have shown that there is a high correlation between the personal traits and the individual's motivation for success or failure, and fully directing task-ego orientation.

The subject of researching success factors in sports has increased rapidly in recent years. Studies conducted on this subject examine the extent of the relationship between achievement motivation and sportive behaviors and other related relationships (Kavussanu \& Ntoumanis, 2007).

Duda, highly influenced by Nicholls' talent theory, suggested two bases for motivation in sports skills and achieving goals. The first is the basic task and goal orientation. Athletes who perceive the goal orientation well will have better improvement in motor skills, learning differently, mastering at learning, acting as a team, and cooperation. Studies show that task and goal orientation have a positive correlation with task satisfaction, enjoyment, and internalizing the sport. The second basis is goal orientation associated with EGO. It shows that individuals with ego orientation, focus on being superior to their competitors, defeating the opponent, and what happens at the end of the game and the result (Duda \& White, 1992). Studies show that lack of goal orientation associated with ego leads to high levels of anxiety, lack of strength in the competition, less enjoyment of the sport, and less satisfaction by being less connected. Athletes with a higher level of task orientation in a sports organization display their mastery strategies better. They believe in doing more intense and qualified training for mastery strategies to emerge. They refrain from being compared with other athletes at their own level, and they identify success perceptions with their own personal development. In the event of loss or failure, they tend to continue their individual success by returning to their own internal motivation. On the contrary, athletes with a higher level of ego orientation, which is the second type of orientation, believe that skills are more important than training 
and that people should turn to themselves when there are difficulties. They may behave unethically to be one step ahead (Duda, 1989).

It is known that there is a high level of relationship between life satisfaction of individuals and their individual games in the goal and paths leading to the goal. It is known that if people are happy and at ease in their private life, they will get the same happiness and pleasure from their success in sports (Toros, 2004).

The life satisfaction of athletes with a high level of goal orientation and ego orientation has a close relationship with cognitive judgments and success. The goal orientation of the athletes with high life satisfaction has a correlation in parallel as well. Not only success, but also enjoying the process comes to the fore. Similarly, the satisfaction and success levels of ego-oriented athletes are highly parallel, but instead of enjoying the work done, the pleasure derived from the result is more prominent (Toros, 2002). This study examines the relationship between the task orientation goals of curling athletes in sports and remote education programs during the pandemic period. In addition, it was investigated whether there is a relationship between task orientation and the connection of goals with personality in sports. This study will provide a prediction for the literature in order to see the level of the athletes who actively compete in the Curling Leagues in this period.

\section{Methodology}

\subsection{Research Group}

This study was conducted with 150 top-level athletes participating in a total of 89 events, 47 male and 42 female participation in top leagues in Turkey Curling Federation. All of these 89 athletes are elite athletes competing at the Super League, 1st League and 2nd League level organized by the federation.

\subsection{Data Collection Tools}

The basic measurement tools in the study are the "Task and Ego Orientation Scale in Sports (SGEYO)" developed by Duda and adapted to Turkish Athletes by Toros, the Eysenck Personality Questionnaire developed by Karanci, and the Pandemic Era Support Scale, which has been reliably and validated by the researcher. The survey consists of four stages (Duda, 1989; Toros, 2004; Karanci, Dirik, \& Yorulmaz, 2007). Demographic features are included in the 1st stage. It consists of 14 questions. At the 2nd stage, the "Task and Ego Orientation Scale in Sports" consisted of 13 items, seven of which are task orientation, and six of which are ego orientation. Those who respond to the scale participate in each article according to the evaluation system of 5. In the third stage, the Eysenck Personality Scale developed by Karanci consists of 23 questions in total. Questions were asked in the form of yes or no. In the 4th stage, a scale developed to determine sports perception and orientation of athletes. In the last stage, there is a scale developed to determine the distance education status of athletes during the pandemic period. They were expected to answer according to the 5 Likert evaluation. 


\section{Ml Macrothink}

The survey applications were made by responding to the Google survey file on the message application sent by phone. An explanation, indicating the aims and objectives of the research, was made at the introduction of the questionnaire application.

\subsection{Data Analysis}

In the analysis of the data, 6 different statistical analyzes were used and these analyzes were made on the computer with the SPSS 22.00 statistical package program. These analyzes are as follows: Frequency distributions of the scales were examined. The percentage values of the participants in the study were taken. Pearson correlation methods were used depending on the level of interaction of the questions on the scale. Primary component factor analysis using the Oblimin rotation method was used to check the construct validity of the scale, item-total correlations were examined, and Cronbach Alpha coefficients were examined for an internal consistency determination. The Cronbach Alpha number was found to be .085. Therefore, representations were made with a value of 0.05 as the error value. T-test was used to determine gender and other measuring devices. The Kruskal Wallis $\mathrm{h}$ test was applied to understand the differences in terms of Eysenck personality survey, Task and Ego Orientation Scale, sport perception and orientation scale, and Distance Education Support Scale scores according to the introductory characteristics of the athletes covered by the research. Dunnet T3 Post Hoc test was applied to determine whether the differences between demographic characteristics and questionnaire scales were significant. Pearson Correlation Techniques were used to look at the level of interaction between questions.

\subsection{Hypotheses of the Research}

- Hypothesis 1: In the Pandemic Context, there is an association between personality traits and demographic features of Curling athletes.

- Hypothesis 2: There is a relationship between task and ego orientation of Curling athletes and Sport perception and Orientation during the pandemic period.

- Hypothesis 3: They continue their growth during the Pandemic Era by having distance education and are focused on the same goals.

- Hypothesis 4: During the pandemic period, there is a relationship between personality traits, task, and ego orientation in sport, perception, and orientation in sports and distance education support they receive.

\section{Findings}

\subsection{Data Analysis}

Table 1 offers details on the identification of the sportsmen included in the analysis concerning their introductory characteristics. 
Table 1. Comparison of athletes in terms of their introductory characteristics

\begin{tabular}{|c|c|c|c|}
\hline & & $\mathrm{n}$ & $\%$ \\
\hline \multirow{6}{*}{ Age } & Age of $15-17$ & 34 & 38.2 \\
\hline & Age of 18-20 & 24 & 27.0 \\
\hline & Age of 21-23 & 12 & 13.5 \\
\hline & Age of 24-26 & 1 & 1.1 \\
\hline & Age of 27-29 & 4 & 4.5 \\
\hline & Age of 30 or older & 14 & 15.7 \\
\hline \multirow{2}{*}{ Gender } & Male & 47 & 52.8 \\
\hline & Female & 42 & 47.2 \\
\hline \multirow{6}{*}{ Doing Sports Year } & $1-3$ years & 50 & 56.2 \\
\hline & 4-6 years & 15 & 16.9 \\
\hline & $7-9$ years & 11 & 12.4 \\
\hline & $10-12$ years & 9 & 10.1 \\
\hline & $13-15$ years & 1 & 1.1 \\
\hline & 16 years and above & 3 & 3.4 \\
\hline \multirow{4}{*}{ Educational Status } & Secondary Education & 36 & 40.4 \\
\hline & High School & 12 & 13.5 \\
\hline & Bachelor's Degree & 35 & 39.3 \\
\hline & Postgraduate & 6 & 6.7 \\
\hline \multirow{4}{*}{ Position Played } & 1 & 28 & 31.5 \\
\hline & 2 & 18 & 20.2 \\
\hline & 3 & 22 & 24.7 \\
\hline & 4 & 21 & 23.6 \\
\hline \multirow{5}{*}{ Licensed Category } & Senior League & 3 & 3.4 \\
\hline & Promotion League & 9 & 10.1 \\
\hline & $2^{\text {nd }}$ League & 32 & 36.0 \\
\hline & $1^{\text {st }}$ League & 15 & 16.9 \\
\hline & Super League & 30 & 33.7 \\
\hline \multirow{4}{*}{ Place to Stay } & With Family & 83 & 93.3 \\
\hline & Bachelor Pad & 2 & 2.2 \\
\hline & State or Private Dormitory & 2 & 2.2 \\
\hline & Club Guest House & 2 & 2.2 \\
\hline
\end{tabular}




\begin{tabular}{|c|c|c|c|}
\hline \multirow{7}{*}{ Father's Profession } & Unemployed & 5 & 5.6 \\
\hline & Insured Worker & 21 & 23.6 \\
\hline & Farmer & 4 & 4.5 \\
\hline & Officer & 15 & 16.9 \\
\hline & Retired & 27 & 30.3 \\
\hline & Industrial Worker & 2 & 2.2 \\
\hline & Craftsman & 15 & 16.9 \\
\hline \multirow{4}{*}{ Father's Education } & Secondary Education & 26 & 29.2 \\
\hline & High School & 37 & 41.6 \\
\hline & Bachelor's Degree & 14 & 15.7 \\
\hline & Postgraduate & 12 & 13.5 \\
\hline \multirow{5}{*}{ Mother's Profession } & Housewife & 78 & 87.6 \\
\hline & Officer & 1 & 1.1 \\
\hline & Insured Worker & 5 & 5.6 \\
\hline & Retired & 3 & 3.4 \\
\hline & Craftsmen and other & 2 & 2.2 \\
\hline \multirow{5}{*}{ Mother's Education } & Illiterate & 15 & 16.9 \\
\hline & Pirmary School & 36 & 40.4 \\
\hline & Secondary Education & 30 & 33.7 \\
\hline & High School & 6 & 6.7 \\
\hline & Bachelor's degree and above & 2 & 2.2 \\
\hline \multirow{5}{*}{ Number of Siblings } & 1 & 1 & 1.1 \\
\hline & 2 & 15 & 16.9 \\
\hline & 3 & 29 & 32.6 \\
\hline & 4 & 29 & 32.6 \\
\hline & 5 and above & 16 & 16.9 \\
\hline
\end{tabular}

When the table is examined, it is seen that $38,2 \%$ of the athletes participated in the study are between the age of $15-17,27 \%$ of them are between $18-20,13.5 \%$ of them are between $21-23$, $1.1 \%$. of them are between $24-26,4.5 \%$ are between $27-29,15.17 \%$ of them are above 30 ; $52.8 \%$ of them are male and $47.2 \%$ of them are female; $56.2 \%$ of them have been doing sports for $1-3$ years, $16.9 \%$ of them have been doing sports for $4-6$ years, $12.4 \%$ of them have been doing sports for $7-9$ years, $10.1 \%$ of them have been doing sports for $10-12$ years, $1.1 \%$ of them have been doing sports for $13-15$ years, $3.4 \%$ of them have been doing sports for 16 years and 
more; $40.4 \%$ of them are secondary school graduate, $13.5 \%$ of them are high school graduate, $39.3 \%$ of them are university graduate, $6.7 \%$ of them are postgraduate; $31.5 \%$ of the athletes play at 1 st position, $20.2 \%$ of them play at 2 nd position, $24.7 \%$ of them play at 3 rd position, $23.6 \%$ of them play at 4 th position; $3.4 \%$ of the athletes compete in the Senior League on a licensed basis, $10.1 \%$ of them compete in Promotion League on a licensed basis, $36 \%$ of them compete in 2nd League on licensed basis, $26.9 \%$ of them compete in 1 st League on a licensed basis, $33.7 \%$ of them compete in Super League on a licensed basis; $93.3 \%$ of the athletes stay with their families, $2.2 \%$ of them stay in bachelor pads, $2.2 \%$ of them stay in state/private dormitories; $5.6 \%$ of the athletes' fathers are unemployed, $23.6 \%$ of the fathers are insured worker, $4.5 \%$ of the fathers are farmers, $16.9 \%$ of the fathers are officers, $30.3 \%$ of the fathers are retired, $2.2 \%$ of the fathers are industrial workers, $16.9 \%$ of the fathers are craftsmen; $29.2 \%$ of the athletes' fathers are primary school graduate, $41.6 \%$ of the fathers are secondary school graduate, $15.7 \%$ of the fathers are high school graduate, $13.5 \%$ of the fathers are undergraduate and postgraduate; $87.6 \%$ of the athletes' mothers are housewives, $1.1 \%$ of the mothers are officers, $5.6 \%$ of the mothers are insured workers, $3.4 \%$ of the mothers are retired, $2.2 \%$ of the mothers are craftswomen and others; $16.9 \%$ of the athletes' mothers are illiterate, $40.4 \%$ of the mothers are primary school graduate, $33.7 \%$ of the mothers are secondary school graduate, $6.7 \%$ of the mothers are high school graduate, $2.2 \%$ of the mothers are university graduate; $1.1 \%$ of the athletes have 1 sibling, $16.9 \%$ of them have 2 siblings, $32.6 \%$ of them have 3 siblings, $32.6 \%$ of them have 4 siblings, and $16.9 \%$ of them have 5 siblings.

In Table 2, Arithmetic on the scores of the athletes in the Eysenck Personality Questionnaire, Task and Ego Orientation in Sports Scale, Sport Perception and Orientation Scale, and Distance Education Support Scale mean and standard deviation values are given.

Table 2. Athletes Eysenck Personality Questionnaire, Task and Ego Orientation Scale in Sports, $\mathrm{C}$ Scale and S Scale arithmetic mean and standard deviation values for the scores

\begin{tabular}{|l|l|l|l|l|l|}
\hline & N & Minimum & Maximum & Aritmetic Mean & S.S. \\
\hline Extroversion dimension & 89 & 0 & 6 & 3.98 & 1.14 \\
\hline Lie dimension & 89 & 2 & 6 & 4.56 & 1.08 \\
\hline Neuroticism dimension & 89 & 0 & 6 & 2.66 & 1.56 \\
\hline Psychoticism dimension & 89 & 0 & 13 & 1.60 & 1.51 \\
\hline Task Orientation dimension & 89 & 7 & 34 & 25.22 & 5.32 \\
\hline Ego Orientation dimension & 89 & 6 & 30 & 18.28 & 5.93 \\
\hline Perception and Orientation of Sports Scale & 89 & 9 & 45 & 37.92 & 6.22 \\
\hline Distance Education Support Scale & 89 & 11 & 45 & 33.94 & 5.87 \\
\hline
\end{tabular}


When the table is examined, it has been seen that Eysenck Personality Questionnaire's mean of the "Extroversion" dimension is 3.98 1 1.14, mean of the "Lie" dimension is $4.56 \pm 1.08$, mean of "Neuroticism" dimension is $2.66 \pm 1.56$, mean of "Psychoticism" dimension is $1.60 \pm 1.51$; Sports Perception and Orientation Scale's mean of "Task Orientation" dimension is $25.22 \pm 5.32$, mean of "ego orientation" dimension is $18.28 \pm 5.93$; mean of Sports Perception and Orientation Scale's is $37.92 \pm 6.22$, and mean of "Distance Education Support Scale" is $33.94 \pm 5.87$.

Pearson correlation analysis was used to find out whether there is a relationship between the scores of Eysenck Personality Questionnaire, Task and Ego Orientation in Sports Scale, Sport Perception and Orientation Scale, and Distance Education Support Scale.

Table 3. Eysenck Personality Questionnaire, Task and Ego Orientation in Sports Scale, Sport Perception and Orientation Scale and Distance Education Support Scale correlation values related to the relationship between the scores of the silenced topics and reasons for silence scores

\begin{tabular}{|c|c|c|c|c|c|c|c|c|}
\hline & & Extroversion & Lie & Neuroticism & Psychotism & Task Orientation & Ego Orientation & $\begin{array}{l}\text { Sports Perception } \\
\text { and Orientation Scale }\end{array}$ \\
\hline \multirow{2}{*}{ Extroversion } & $\mathrm{r}$ & 1 & & & & & & \\
\hline & $\mathrm{p}$ & & & & & & & \\
\hline \multirow{2}{*}{ Lie } & $\mathrm{r}$ & .150 & 1 & & & & & \\
\hline & $\mathrm{p}$ & .162 & & & & & & \\
\hline \multirow{2}{*}{ Neuroticism } & $r$ & -.107 & $-.211^{*}$ & 1 & & & & \\
\hline & $\mathrm{p}$ & .319 & .047 & & & & & \\
\hline \multirow{2}{*}{ Psychotism } & $\mathrm{r}$ & .127 & .030 & .140 & 1 & & & \\
\hline & $\mathrm{p}$ & .235 & .783 & .191 & & & & \\
\hline \multirow{2}{*}{ Task Orientation } & $\mathrm{r}$ & .097 & -.155 & -.026 & .060 & 1 & & \\
\hline & $\mathrm{p}$ & .367 & .146 & .806 & .578 & & & \\
\hline \multirow{2}{*}{ Ego Orientation } & $\mathrm{r}$ & .188 & -.059 & -.207 & .036 & $.650^{* * *}$ & 1 & \\
\hline & $\mathrm{p}$ & .078 & .584 & .051 & .739 & .000 & & \\
\hline \multirow{2}{*}{$\begin{array}{l}\text { Sports Perception and } \\
\text { Orientation Scale }\end{array}$} & r & -.039 & -.153 & .118 & -.100 & .170 & .161 & 1 \\
\hline & $\mathrm{p}$ & .718 & .153 & .271 & .349 & .111 & .131 & \\
\hline \multirow{2}{*}{$\begin{array}{l}\text { Distance Education } \\
\text { Support Scale }\end{array}$} & $\mathrm{r}$ & .119 & -.079 & .036 & -.080 & .168 & .027 & $.586^{* *}$ \\
\hline & $\mathrm{p}$ & .267 & .459 & .735 & .458 & .115 & .800 & .000 \\
\hline
\end{tabular}

Note. $(*) \mathrm{p}<0.05 ;(* *) \mathrm{p}<0.001$.

When the table is examined, it is seen that the correlation values between the "lie" dimension scores and the "neuroticism" dimension scores of the Eysenck Personality Questionnaire were 
found to be inversely significant, the correlation values between the "task orientation" dimension scores and the "ego orientation" dimension scores of the Task and Ego Orientation Scale in Sport were significant in the right direction, and the correlation values between the "sports perception and orientation" scale scores and correlation values between" sports perception and orientation "scale scores and" Distance Education Support " scale scores were found to be significant in the right direction.

As a result, it can be said that "neuroticism" dimension scores will decrease as the "lie" dimension scores of the Eysenck personality survey increase; as "Task Orientation" dimension of Task in Sport and Ego Orientation Scale increases, the dimension of "ego orientation" will increase, too; "Distance Education Support Scale's scores will increase as "Sports Perception and Orientation Scale" scores increase.

Differences in the Eysenck Personality Questionnaire, Task and Ego Orientation Scale in Sports, Perception and Orientation Scale in Sports and Distance Education Support Scale scores are given in Table 4 according to the introductory characteristics of the athletes.

Table 4. Differences in terms of scores of Eysenck Personality Questionnaire, Task and Ego Orientation in Sports Scale, Scale C, and S Scale according to the introductory characteristics of athletes

\begin{tabular}{|c|c|c|c|c|c|c|c|c|c|}
\hline & & Extroversion & Lie & Neuroticism & Psychoticism & $\begin{array}{l}\text { Task } \\
\text { Orientation }\end{array}$ & $\begin{array}{l}\text { Ego } \\
\text { Orientation }\end{array}$ & $\begin{array}{l}\text { Sports } \\
\text { Perception } \\
\text { and } \\
\text { Orientation } \\
\text { Scale }\end{array}$ & $\begin{array}{l}\text { Distance } \\
\text { Education } \\
\text { Support } \\
\text { Scale }\end{array}$ \\
\hline \multirow{8}{*}{ 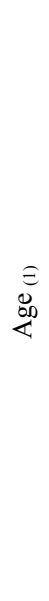 } & Age of $15-17$ & 46.56 & 39.65 & 44.40 & 38.74 & 49.01 & 51.34 & 47.34 & 44.91 \\
\hline & Age $18-20$ & 41.27 & 38.10 & 51.52 & 45.88 & 46.15 & 45.88 & 49.71 & 53.33 \\
\hline & 21-23 yaş & 43.25 & 54.67 & 49.13 & 55.17 & 42.75 & 42.54 & 43.00 & 48.46 \\
\hline & 24-26 yaş & 41.50 & 56.50 & 4.00 & 62.50 & 47.50 & 27.00 & 12.50 & 40.50 \\
\hline & $27-29$ yaş & 50.75 & 53.75 & 20.50 & 59.38 & 38.88 & 35.63 & 50.88 & 67.88 \\
\hline & $30+$ & 47.71 & 58.21 & 41.68 & 44.64 & 36.79 & 34.18 & 33.61 & 21.75 \\
\hline & TEST & $\begin{array}{l}K W=1.172 \\
p=.948\end{array}$ & $\begin{array}{l}K W=9.958 \\
p=.076\end{array}$ & $\begin{array}{l}K W=8.491 \\
p=.131\end{array}$ & $\begin{array}{l}K W=6.273 \\
p=.281\end{array}$ & $\begin{array}{l}K W=2.630 \\
p=.757\end{array}$ & $\begin{array}{l}K W=5.675 \\
p=.339\end{array}$ & $\begin{array}{l}K W=5.690 \\
p=.338\end{array}$ & $\begin{array}{l}K W=17.31 \\
p=.004\end{array}$ \\
\hline & Difference & - & - & - & - & - & - & - & $1-2-3-4-5>6$ \\
\hline \multirow{3}{*}{$\begin{array}{l}\text { व } \\
\dot{0} \\
\stackrel{0}{0} \\
0\end{array}$} & Male & $3.98 \pm 1.21$ & $4.68 \pm 1.09$ & $2.40 \pm 1.58$ & $1.38 \pm 0.87$ & $24.51 \pm 5.34$ & $18.13 \pm 5.58$ & $37.72 \pm 7.47$ & $33.60 \pm 6.77$ \\
\hline & Female & $3.98 \pm 1.07$ & $4.43 \pm 1.06$ & $2.95 \pm 1.50$ & $1.83 \pm 1.97$ & $26.02 \pm 5.23$ & $18.45 \pm 6.37$ & $38.14 \pm 4.52$ & $34.33 \pm 4.72$ \\
\hline & TEST & $\begin{array}{l}t=.010 \\
p=.992\end{array}$ & $\begin{array}{l}t=1.105 \\
p=.272\end{array}$ & $\begin{array}{l}t=-1.673 \\
p=.098\end{array}$ & $\begin{array}{l}t=-1.417 \\
p=.160\end{array}$ & $\begin{array}{l}t=-1.347 \\
p=.181\end{array}$ & $\begin{array}{l}t=-.256 \\
p=.798\end{array}$ & $\begin{array}{l}t=-.316 \\
p=.753\end{array}$ & $\begin{array}{l}t=-.590 \\
p=.557\end{array}$ \\
\hline
\end{tabular}




\begin{tabular}{|c|c|c|c|c|c|c|c|c|c|}
\hline \multirow{8}{*}{ 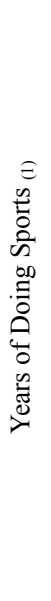 } & $1-3$ years & 45.02 & 40.00 & 46.38 & 41.65 & 44.88 & 44.74 & 47.10 & 46.52 \\
\hline & $4-6$ years & 46.20 & 42.53 & 50.73 & 57.30 & 53.73 & 52.63 & 47.90 & 50.10 \\
\hline & $7-9$ years & 37.32 & 50.14 & 41.73 & 37.36 & 37.73 & 42.00 & 50.36 & 54.77 \\
\hline & $10-12$ years & 49.72 & 66.11 & 32.39 & 43.72 & 35.56 & 41.61 & 31.94 & 26.44 \\
\hline & $13-15$ years & 73.00 & 56.50 & 51.00 & 83.50 & 39.00 & 67.50 & 52.50 & 63.00 \\
\hline & $16+$ & 43.33 & 54.67 & 41.17 & 58.33 & 60.33 & 24.83 & 12.50 & 8.00 \\
\hline & TEST & $\begin{array}{l}K W=2.782 \\
p=.734\end{array}$ & $\begin{array}{l}K W=9.852 \\
p=080\end{array}$ & $\begin{array}{l}K W=3.440 \\
p=.632\end{array}$ & $\begin{array}{l}K W=9.260 \\
p=.099\end{array}$ & $\begin{array}{l}\mathrm{KW}=4.939 \\
\mathrm{p}=.423\end{array}$ & $\begin{array}{l}K W=4.222 \\
p=.518\end{array}$ & $\begin{array}{l}\mathrm{KW}=\mathbf{8 . 1 6 8} \\
\mathrm{p}=.147\end{array}$ & $\begin{array}{l}K W=13.686 \\
p=.018\end{array}$ \\
\hline & Difference & - & - & - & - & - & - & - & $1-2-3>4-6$ \\
\hline \multirow{6}{*}{ 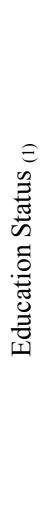 } & $\begin{array}{l}\text { Secondary } \\
\text { Education }\end{array}$ & 39.40 & 41.00 & 45.25 & 43.53 & 46.04 & 46.79 & 45.03 & 45.90 \\
\hline & High School & 55.04 & 38.54 & 52.42 & 38.17 & 55.17 & 50.58 & 50.17 & 50.67 \\
\hline & Bachelor's Degree & 46.86 & 48.86 & 44.00 & 46.57 & 40.10 & 43.37 & 48.01 & 42.69 \\
\hline & Postgraduate & 47.67 & 59.42 & 34.50 & 58.33 & 47.00 & 32.58 & 16.92 & 41.75 \\
\hline & TEST & $\begin{array}{l}K W=4.182 \\
p=.242\end{array}$ & $\begin{array}{l}K W=4.628 \\
p=.201\end{array}$ & $\begin{array}{l}K W=2.108 \\
p=.550\end{array}$ & $\begin{array}{l}K W=3.015 \\
p=.389\end{array}$ & $\begin{array}{l}K W=3.237 \\
p=.356\end{array}$ & $\begin{array}{l}K W=2.268 \\
p=.519\end{array}$ & $\begin{array}{l}K W=8.090 \\
p=.044\end{array}$ & $\begin{array}{l}K W=1.002 \\
p=.801\end{array}$ \\
\hline & Difference & - & - & - & - & - & - & $1-2-3>4$ & - \\
\hline \multirow{5}{*}{ 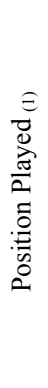 } & 1 & 44.68 & 38.77 & 51.04 & 44.59 & 43.63 & 43.00 & 45.14 & 48.23 \\
\hline & 2 & 49.72 & 49.64 & 39.36 & 43.72 & 39.78 & 38.08 & 44.78 & 50.17 \\
\hline & 3 & 47.39 & 48.70 & 44.18 & 50.32 & 50.02 & 51.32 & 42.64 & 40.52 \\
\hline & 4 & 38.88 & 45.45 & 42.64 & 41.07 & 46.05 & 46.98 & 47.48 & 40.95 \\
\hline & TEST & $\begin{array}{l}K W=2.200 \\
p=.532\end{array}$ & $\begin{array}{l}K W=2.898 \\
p=.408\end{array}$ & $\begin{array}{l}K W=2.674 \\
p=.445\end{array}$ & $\begin{array}{l}K W=1.650 \\
p=.648\end{array}$ & $\begin{array}{l}K W=1.694 \\
p=.638\end{array}$ & $\begin{array}{l}K W=2.909 \\
p=.406\end{array}$ & $\begin{array}{l}K W=.381 \\
p=.944\end{array}$ & $\begin{array}{l}K W=2.347 \\
p=.504\end{array}$ \\
\hline
\end{tabular}

Note. Rank mean (2) Arithmetic mean and standard deviation (1). 


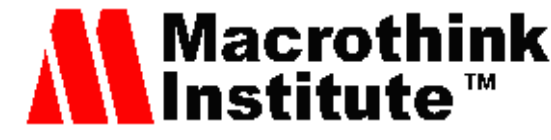

Table 4. Continued

\begin{tabular}{|c|c|c|c|c|c|c|c|c|c|}
\hline & & Extroversion & Lie & Neuroticism & Psychoticism & $\begin{array}{l}\text { Task } \\
\text { Orientation }\end{array}$ & $\begin{array}{l}\text { Ego } \\
\text { Orientation }\end{array}$ & $\begin{array}{l}\text { Sports } \\
\text { Perception } \\
\text { and } \\
\text { Orientation } \\
\text { Scale }\end{array}$ & $\begin{array}{l}\text { Distance } \\
\text { Education } \\
\text { Support } \\
\text { Scale }\end{array}$ \\
\hline \multirow{6}{*}{ 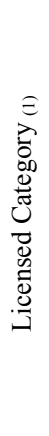 } & Senior League & 48.17 & 28.00 & 44.33 & 32.67 & 57.50 & 46.67 & 73.67 & 70.00 \\
\hline & Promotion League & 44.22 & 48.94 & 25.72 & 35.17 & 44.11 & 58.17 & 42.89 & 50.50 \\
\hline & $2^{\text {nd }}$ League & 41.73 & 40.56 & 50.08 & 43.13 & 40.41 & 45.25 & 47.69 & 39.39 \\
\hline & $1^{\text {st }}$ League & 53.70 & 50.17 & 47.57 & 49.93 & 43.90 & 39.13 & 40.20 & 46.33 \\
\hline & Super League & 44.05 & 47.67 & 44.15 & 48.72 & 49.47 & 43.55 & 42.30 & 46.17 \\
\hline & TEST & $\begin{array}{l}K W=2.574 \\
p=.632\end{array}$ & $\begin{array}{l}K W=3.662 \\
p=.454\end{array}$ & $\begin{array}{l}K W=6.658 \\
p=.155\end{array}$ & $\begin{array}{l}K W=3.734 \\
p=.443\end{array}$ & $\begin{array}{l}K W=2.670 \\
p=.615\end{array}$ & $\begin{array}{l}K W=3.235 \\
p=.519\end{array}$ & $\begin{array}{l}K W=4.973 \\
p=.290\end{array}$ & $\begin{array}{l}K W=4.853 \\
p=.303\end{array}$ \\
\hline \multirow{5}{*}{ 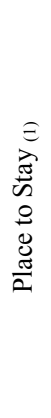 } & With Family & 44.40 & 44.99 & 45.61 & 45.17 & 45.67 & 46.58 & 45.66 & 45.16 \\
\hline & Bachelor Pad & 22.25 & 28.00 & 42.25 & 47.75 & 31.25 & 29.75 & 43.75 & 16.25 \\
\hline & $\begin{array}{l}\text { State or Private } \\
\text { Dormitory }\end{array}$ & 80.25 & 53.75 & 25.00 & 34.50 & 42.75 & 31.00 & 47.00 & 75.75 \\
\hline & Club Guest House & 57.25 & 53.75 & 42.50 & 45.75 & 33.25 & 8.50 & 17.00 & 36.25 \\
\hline & TEST & $\begin{array}{l}\mathrm{KW}=6.437 \\
\mathrm{p}=.092\end{array}$ & $\begin{array}{l}K W=1.439 \\
p=.696\end{array}$ & $\begin{array}{l}K W=1.332 \\
p=.722\end{array}$ & $\begin{array}{l}K W=.402 \\
p=.940\end{array}$ & $\begin{array}{l}K W=1.059 \\
p=.787\end{array}$ & $\begin{array}{l}K W=5.612 \\
p=.132\end{array}$ & $\begin{array}{l}\mathrm{KW}=2.433 \\
\mathrm{p}=.488\end{array}$ & $\begin{array}{l}K W=5.573 \\
p=.134\end{array}$ \\
\hline
\end{tabular}

When the table was examined, the KW value of the differences between them in terms of Distance Education Support Scale scores according to the age of the athletes was found to be significant at the importance level of $p<0.05$. These findings suggest that there is a difference between athletes in terms of Distance Learning Support scale scores based on their age. Dunnet T3 Post Hoc test was applied to understand the difference between athletes at which age. The Dunnet T3 Hoc test result found that athletes aged 15-17 years, 18-20 years, 21-23 years, 24-26 years, 27-29 years had higher Distance Education Support Scale scores than athletes aged 30 years or older.

When the table was examined, it was found that the KW value of the differences between athletes in terms of Distance Education Support Scale scores compared to the year of sports was significant at the level of $p<0.05$. These findings claim that there is a difference between athletes in terms of Distance Learning Support scale scores based on their age. To understand that there is a difference between athletes who have a sporty year, Dunnet T3 Post-Hoc test was applied. As a result of the Dunnet T3 Hoc test, it was found that athletes with a sports year of 1-3 years, 4-6 years, 7-9 years had higher S Scale scores than athletes with a sports year of $10-12$ years and 16 years and above. 


\section{Macrothink}

When the table was examined, the KW value of the differences between them in terms of Sports perception and orientation scale scores according to the training status of the athletes was found to be significant at the importance level of $p<0.05$. These findings show that there is a difference between athletes in terms of their perception of sport and orientation scale scores based on their training status. Dunnet T3 Post Hoc test was used to explain the athlete gap at which age. Athletes with Dunnet experience in elementary, high school, and undergraduate experience were found to have a higher perception of sports and scale of orientation scores than graduate-educated sportsmen. When the table was examined, the KW value of the differences between the athletes in terms of neuroticism scores according to the profession of their mothers was found to be significant at the importance level of $p<0.05$. These findings suggest that there is a difference between athletes in terms of neuroticism scores by their mothers' profession. Dunnet T3 Post Hoc test was applied to recognize that athletes whose mothers are housewives differ. The Dunnet T3 Hoc test result found that athletes whose mother was a housewife had higher neuroticism scores than athletes whose mother retired.

When the table is examined, the gender of the athletes, position, category in which they competed as licensed, place of stay, father's profession, father's education, mother's education and the number of siblings by, Eysenck Personality Questionnaire, Task and Ego Orientation in Sports Scale, Sport Perception and Orientation Scale and Distance Education Support Scale Statistical analysis results of the differences between them in terms of scores were found to be insignificant at $\mathrm{p}>0.05$ significance level. These results indicate that there is no disparity between athletes in terms of gender, position, a category they compete as licensed, place of stay, father's occupation, father's education, mother's education and a number of siblings, Eysenck personality test, task and self-orientation scale in Sport, perception and orientation scale in Sport, and scale of Distance Education Support.

Eysenck Personality Questionnaire, Sport Scale Role and Ego Orientation, Sport Perception and Orientation Scale, and Distance Education Support Scale Cronbach Alpha Coefficient are measured to find continuity of internal structure. 
Table 5. The Eysenck Personality Questionnaire was used to determine whether the Task and Ego Orientation in Sports Scale, the C Scale and the S Cronbach Alpha coefficient of the scale

\begin{tabular}{|c|c|c|c|}
\hline Scales & \multicolumn{2}{|c|}{ Cronbach's Alpha coefficient } & Number of Items \\
\hline Extroversion & \multicolumn{2}{|c|}{.322} & 6 \\
\hline Lie & \multicolumn{2}{|c|}{.129} & 6 \\
\hline Neuroticism & \multicolumn{2}{|c|}{.493} & 6 \\
\hline Psychoticism & \multicolumn{2}{|c|}{.109} & 5 \\
\hline Task Orientation & \multicolumn{2}{|c|}{.802} & 7 \\
\hline Ego Orientation & \multicolumn{2}{|c|}{.905} & 6 \\
\hline Sports Perception and Orientation Scale & \multicolumn{2}{|c|}{.863} & 9 \\
\hline \multirow[t]{2}{*}{ Distance Education Support Scale } & \multicolumn{2}{|c|}{.777} & 9 \\
\hline & $\mathrm{N}$ & $\%$ & Cronbach's Alpha \\
\hline Valid & 89 & 94.7 & \multirow{3}{*}{.850} \\
\hline Excluded $^{\mathrm{a}}$ & 5 & 5.3 & \\
\hline Total & 94 & 100.0 & \\
\hline
\end{tabular}

\section{Discussion, Conclusion, and Suggestions}

\subsection{Discussion and Conclusion}

The purpose of this study is to assess the ego-task orientation of Curling athletes, personality analysis, and the status of remote support in sports, and to determine the level of relationship between these scales. Curling participants are found to have levels of high task ego focus and task-driven goals. It is seen in the field studies that ego and role orientation profiles in other sport divisions have similar values according to the findings collected. It has been observed that they have lower values than sports such as basketball, football, hockey, rugby, and similar values with elite young wrestlers. Besides, common ideals arose in terms of individual athletes' mission and ego-orientation. But it has been seen to have fewer values than team sports (Kavussanu \& Ntoumanis, Participation in Sport and Moral Functioning: Does Ego Orientation Mediate Their Relationship?) (Pol et al., 2012).

If we look at it from another perspective, the COVID-19 Pandemic has completely affected people's life. Countries' online banking systems, online shopping systems over the internet, corporate online transactions, online workplace network connections and remote working systems, online training and program development, etc. new opportunities have begun to be more intimate. Although the "Digital World or Digitalization" phenomenon brings comfort to some, it is a condition that needs to be addressed and takes over life to others, it is called an 'unnecessary' phenomenon to others. 
Educational institutions in countries are starting to make a rapid transition to the digital world. The Ministries of Education of several countries and their federations made a very fast transition to online education. They were not able to keep up with this transition very fast in some countries, but they are working on preparation by spreading it over time. Today the country's sports federations are seeking to improve their versatility in the same way and these distance education channels are training their athletes in all categories for potential competitions in the future.

It has been observed that there are significant differences between an athlete's goal and task perspective and the sport's male or female athletes. Our study is backed by similar findings in studies on male and female high school athletes (Acet et al., 2016). One of the factors which increase the success rates of athletes who are more competitive and can sustain a high level of competition, enjoy their job, have high motivation, and respect their opponent is a sense of belonging and identity in sports. Good analysis of the task and ego orientation provides great information about athletes' motivation for success (Duda, 1992; Fox et al., 1994).

Studies performed with mission orientation and ego indicate that athletes are typically highly motivated, as well as creating internal motivating mechanisms according to the nature of the sport. In this sense, the trainers or trainers should give attention to doing special studies on these issues, no matter which sport they work with (Cakaloglu et al., 2019; Kostuk et al., 2001). Another task in the leagues that athletes play is the factor that affects the ego orientation. In related research, it is shown that their role and ego-orientations increase as the leagues in which the athletes compete (Ozsarı \& Cetin, 2019). Furthermore, it is shown that the negative effects of certain emotions occur in athletes with a higher degree of cognitive anxiety, and this rise, which may increase dramatically before the competition relative to body anxiety, did not improve or sustain this degree both before and during the competition (Moran, 2005; Ozçelik, 2012). Technological developments in sports have made it easier to evaluate athletes from many factors. Applications in sports analysis have begun to reveal both the technical tactics and mental and cognitive processes more clearly and easily (Park \& Lee, 2013).

Being a social being, humans are born with the need to learn. Athletes can learn different cognitive levels both during training and during the competition (Kalkavan et al., 2016). All training and studies have their ego and task orientations. The aim is to ensure that the individual reaches satisfaction and experiences a high level of satisfaction, whether sports activities are reactive or competitive. Athletes reach the top in ego and mission orientation, which is the following step, by enhancing the athletes' motivation, skills, and mental abilities. This creates a phenomenon that improves the development of sports (Serçek et al., 2017; Bayrakdaroğlu et al., 2015).

The term personality comes from the Latin word "persona". As the main meaning, the meaning of "mask" used by theater actors in Latin is its real equivalent. Since it represents a person's mask both in himself and in others, it makes the sense very distinct. The person is in a constant relationship with his environment. His feelings, opinions, attitudes, and actions seek to influence the person in this relationship for that purpose (Koknel, 1997). It includes consistent and continuous behavior patterns that originate from an individual. And pattern behaviors are 
characteristics that distinguish a person from others that are unique to him (Oztürk \& Ulusahin, 2018). Many scientists have done studies on personality development and, in this development, they have usually seen two principles as influences. One of them is heredity and the other one is the environmental impact. In the analyzes made by many researchers from the past to the present, how people think, how they express their thoughts on their actions, and how they form their behaviors is very important (Con, 2011; Vealey, 2002).

When the study results are analyzed, it is shown that there is an inverse and important relationship between the increase of the dimension of lie between personality traits and the scores of the dimension of neutralism. It is observed that the education provided by the parents in which the child is raised or the parents' education is successful in raising the children. Father and mother's attitudes have a defining role here. It affects all developmental stages of the athletes. Based on this, family education is very important in determining the personality traits of an athlete. It has shown the efficacy of the personality and the sports division in a report on the motivational impact of sports (Weiss \& Ferrer-Caja, 2002). Many personal and physical characteristics of individuals engaged in active sports activities differ from those who do not (Cogalgil \& Kishali, 2010). A parallel finding emerged with the research we carried out on personality in a sample of non-athletic pre-school teachers. It has been observed that there is a significant relationship between the dimension of lying and the education level of the mother (Deniz \& Kesicioğlu, 2012). Scientists studying personality have seen personality as one of the most important criteria that determine long-term success in sports. They also found broad and important variations in personality in research performed between those who do sports and those who do not. It demonstrates that habits are challenged because the personality is developed over time and is more involved and participatory in his involvement in life (Karanc1, et al., 2007; Cavdar, 2019; Allen et al., 2013). Another study shows that athletes with personality disorders can disrupt the team spirit in team sports and disrupt the individual potential of other athletes. And it has been shown that they would find it difficult to achieve the complex tasks assigned to them (Marchant \& Petah, 2004). Furthermore, it is claimed that the purpose of training, which affects mental processes in the sentences given, would result in a more positive attitude using positive reinforcements (Ozen \& Eygu, 2010). Besides, a personality emerges as a determining factor in sports based on mental and physical strength. Extreme sports particularly, action sports, chess, tennis, etc. In sports, the determination is very prominent in extreme sports particularly, action sports, chess, tennis, etc. In sports, the determination is very prominent (Yiğit et al., 2016). And it has shown that personality is divided into an adventurous, rational, dreamy, and simple seer. Besides, personality plays an important role in determining the moral levels of those who are engaged in physical education and sports (Coetzee, 2010; Erdogan, 2018). In another study conducted between men and women playing football, it was found that no major variations were depending on the leagues, sexes, years of playing, and female athlete's educational status (Arpa, 2019).

In today's world, human beings have revealed a new life perspective by changing their life values. With the development of technology, he left more free time and wanted to actively use it (Agaoglu \& Boyaci, 2013). In the process of establishing his personality, he carries out several practices while free from his job. These leisure times are sometimes compulsory and 
sometimes occur in the flow of natural life. People who want to relax both mentally and physically develop and incorporate leisure activities at this stage (Turkay et al., 2005). Education, science, and technology come across as three basic concepts intertwined with each other. The developmental dimension of education has also improved science. In parallel, technological developments have inevitably gained great momentum. As a result, it is no longer a denial that a trainer teaches at home. The limits of internet support have widened, and they have been made accessible everywhere, depending on scientific progress (Dogu, 2017). With Internet technology, teacher, student, and class relationships can easily come together without relying on time and location (Haymana, 2019). Athlete-coach interaction and communication began to exist not only in the playground but in all physical spaces (Oz, 2007). Training plans and training plans depend on many different factors. In short, it varies depending on the sport's characteristics, the athlete's age, the intent of training, its complexity, consistency, and level of repetition (Turkey Football Federation, 2020). The working period when it is most efficient and effective for an athlete is seen as the training they do with their teammates. Because the athlete is constantly interacting with his teammate, he looks at him and sees his mistakes and learns from him. The athlete is affected by many factors, whether it is the moment of the match or before it (Yilmaz et al., 2019).

One of the most important and hidden factors affecting the athlete is psychological factors. Although training is commonly known to consist of techniques and strategies, psychological factors are the greatest force influencing such practicing. Athletes use many training models both on and outside the playground. While such activities also involve physical processes, they can include off-field mental processes (Baser, 1986; Turkish Volleyball Fedariton, 2018). But it takes a great deal of effort to activate these mental processes. It is necessary to plan very well and ensure the active participation of the athlete (Yorulmazlar, 2020; İkizler, 1999). It includes a prior preparation process for learning and implementing a movement. Studies show that the organism gives the same body reactions in mental training. Mental training offers many advantages over physical ones (Gursel \& Koruc, 2004). Developing different application strategies has great advantages as it causes less damage and less muscle wear (Baser, 1986). No matter what training model the athlete uses, he/she uses energy by pushing his/her limits at the time of the competition. This applies to mental processes (Cogalgil \& Kishali, 2010). Exercises with mental processes enable the athlete to apply a program suitable for his situation (Bicer, 1997). It makes it easier for him to find the most suitable ways for him. He/she can control his/her emotions. Improves concentration. It makes it easy to find new strategies. His confidence increases. It provides preparation for the process without being injured it increases their technical and physical skills. Provides the opportunity to correct mistakes in simple ways (Ozbay \& Oncu, 2012; Aktepe, 2006). An athlete may be anxious and anxious before, during the competition (Aktaş et al., 2004). This situation is called competition anxiety. Often this tendency is referred to as avoidance of failure (Gill et al., 2017).

It is seen in our research that there is a positive association between age status and the method of distance education of athletes who are older in sport. Older athletes can be more active than other athletes in remote training support and activating mental processes. However, a study 
shows that students require more face-to-face training but it can be adequate in their distance education with appropriate planning (Eygu \& Karaman, 2013).

Because of the coronavirus epidemic, in our country, where part of the sports world has changed from home to work model, it is also a necessity to conduct training online. Federation teachers also benefit from this technological advancement with the widespread introduction of distance education video conferencing technology or strive to gradually adapt to this method. Apart from the different programs, social media tools and search browsers on the Internet, millions of educational and informative contents that are paid or free, in this new period, it is necessary to foresee that the motivation of learning can increase by presenting educational content through video information platforms of people from different disciplines (Digitalage, 2020).

\subsection{Conclusion}

With the spread of the COVID 19 virus, athletes must carry out the necessary work to prepare them for the season in which they will compete by undergoing distance training programs at home. This phenomenon is of great importance for professional athletes to reach the same form again after the epidemic. At this point, various tests are being done on athletes to see the athletes' status. Many researchers carry out intensive studies to determine Ego orientation in sports. More than one study has been conducted to make sense of many feelings and feelings that are included in the task responsibilities of athletes, especially with scales with proven reliable and valid. The Ego and Task Orientation in Sports Scale, developed by Toros for the evaluation of adult athletes during the competitions, is of great importance for them to recognize themselves and produce solutions in achieving success (Duda, 1992). Besides, the Eysenck personality survey developed by Karanci would make it easier to determine the personality traits of athletes or individuals on the road to success (Karanci, Dirik, \& Yorulmaz, 2007).

From the athletes' point of view, an assessment was provided to see how the athletes spend this time during this mandatory quarantine period, and to see at what stage the athletes are doing predictive analysis on this issue. It is thought that there is a possible deficiency in the literature about this sense and it is thought that a study needs to be done. This study was conducted to assess the participants playing in Curling leagues' ego preference and personality characteristics.

According to the analysis of the athletes who participated in our research, there is a positive significant relationship between the lying component of the Personality questionnaire and the Neuroticism and Mission and Ego orientation dimensions. It is also seen that there is a positive significant relationship between the Lying sub-dimension and the Neuroticism sub-dimensions' Sport Perception and Orientation. In other words, it can be assumed that the understanding and orientation of sports increases as the personality grows too. Besides, it is seen that there is a positive relationship with Distance Education support. Furthermore, as the dimensions of Ego and Task Orientation in Sports increase, it is thought that both perceptions of sports and orientation and perception of distance education support will increase. 


\section{Macrothink}

There is a practical approach to promoting distance education, as the athletes' age grows, according to the calculation made in terms of the athletes' ages. Moreover, as the years of doing sports increase, so does the way the athlete perceives support for distance education. It has been noted, however, that athletes' understanding of sports and orientation at junior, high school, and undergraduate levels is more important than graduate athletes. In terms of gender, position, and licensed category, it was seen that there was no significant difference in all measurements. It can be said that the four hypotheses that we put forward come true. It is found that there is a positive relationship between the demographic features and personality characteristics of the athletes whose training and competitions are delayed, as well as between their mission and ego orientations. Besides, it is revealed that athletes over the age of 30 better grasp the training support that athletes receive from a distance.

\subsection{Recommendations}

- As a result of our research, the following suggestions can be listed.

Athletes' personality characteristics and the role and ego orientations can be measured by extending this research to various sport branches.

- By looking at the athletes' perception of sports, the transition to professionalism can be reduced to lower ages.

- For Ego and task orientation in sports, not only the periods of active sports but also the duty and ego orientations can be taken into consideration during the periods of interruption to sports competitions.

- Increased mental strength can be accomplished by encouraging athletes to reach distance training during times of competition.

- Researchers from various fields will focus on Curling athletes and athletes participating in other athletic divisions, which will boost the science sector and put together different disciplines.

\section{Reference}

Acet, M., Canbaz, M., Taner, Y., \& Işık, U. (2016). Investigation of Taekwondo Referee s and Trainers Level of Ego Personality and Aggressiveness According to Gender Factor. International Journal of Science Culture and Sport, 4(17), 156-166. https://doi.org/ 10.14486/IntJSCS544

Ağaoğlu, Y. S., \& Boyac1, M. (2013). Serbest Zaman Eğitimi. Spor Yönetimi ve Bilgi Teknolojileri Dergisi, 8(1), 17-23.

Aktas, Z., Cobanoglu, G., \& Yazicilar, İ. (2004). Profesyonel Erkek Basketbolcuların Saldırganlık Düzeyleri İle Maç Başarıları Arasındaki İlişkinin Araştırılması. Spormetre Beden Ĕgitimi ve Spor Bilimleri Dergisi, 2(3), 127-134. https://doi.org/10.1501/Sporm_0000000143

Aktepe, K. (2006). Sporda Zihinsel Antrenmanın Onemi ve Ferdi Milli Sporcularin Zihinsel Antrenman Bilgi ve Uygulama Düzeylerinin Tespiti (p. 4). Niğde Universitesi Sosyal Bilimler Enstitüsü, Beden Eğitimi ve Spor Anabilim Dalı. 
Akyuz, O. (2017). Müsabaka Dönemindeki Futbolcularda Sekiz Haftalık Antrenmanın Bazı Fiziksel Uygunluk Parametreleri Üzerine Etkisi. Gaziantep Üniversitesi Spor Bilimleri Dergisi, 2(1), 85-95.

Allen, M. S., Iain, G., \& Marc, J. (2013). Personality In Sport: A Comprehensive Review. International Review of Sport and Exercise Psychology, 6(1), 184-208. https://doi.org/ 10.1080/1750984X.2013.769614

Arat, T., \& Bakan, Ö. (2014). Uzaktan Eğitim ve Uygulamaları. Sosyal Bilimler Meslek Yüksek Okulu Dergisi, 14(1-2), 363-374.

Arpa, G. E. (2019). Farklı Liglerdeki Kadın ve Erkek Futbolcuların Fiziksel Benlik Algı Düzeylerinin Incelenmesi (p. 12, Fırat Üniversitesi Sağlık Bilimleri Enstitüsü, Yüksek Lisans Tezi). https://doi.org/10.14225/Joh1555

Aydin, M. (2017). Uzaktan Öğretici Yeterliliklerinin ve Yeterlilik Boyutlarının Belirlenmesi (pp. 50-54, Karadeniz Teknik Universitesi Eğitim Bilimleri Enstitüsü Bilgisayar ve Ögretim Teknolojileri Eğitimi A.B.D. Yüksek Lisans Tezi).

Baser, E. (1986). Uygulamal Spor Psikolojisi: Perfomans Sporunda Psikolojinin Rolü. Ankara: Milli Eğitim Gençlik ve Spor Bakanlığı Yayınları.

Bayrakdaroglu, S., Songun, Y., \& Imamoglu, R. (2015). Hopelessness Levels of Candidate Students of Physical Education and Sports Teaching Department and Their Attitudes Towards Teaching Profession. International Journal of Sport Culture and Science, 3(4), 64-71.

Bicer, T. (1997). Yaşamda ve Sporda Doruk Performans. Istanbul: Beyaz Yayınları.

Cakaloglu, E., Akyuz, O., Sulu, B., \& Bayar, P. (2019). Profesyonel Futbolcularda Hedef Yöneliminin Motivasyonel Yönelim Uzerine Etkisi. Spormetre Dergisi, 17(4), 265-274. https://doi.org/10.33689/spormetre.637261

Cavdar, C. (2019). Lise Og̃rencilerinin Rekreasyonel Faaliyetlere Eğilimleri ve Rekreasyonel Faaliyetlere Katılımlarına Engel Olan Faktörler (p. 45, Necmettin Erbakan Üniversitesi, Sosyal Bilimler Enstitüsü, Rekreasyon ABD, Yüksek Lisans Tezi).

Coetzee, N. (2010). Personality Profiles Of Recreational Scuba Divers: Biokinetics And Sport Science. African Journal for Physical Health Education, Recreation and Dance, 16(4), 568-579. https://doi.org/10.4314/ajpherd.v16i4.63416

Cogalgil, S., \& Kishali, N. F. (2010). Spor Yapan ve Yapmayan Sayan Universite Öğrencilerinin Fiziksel ve Fizyolojik Özelliklerinin Karşılaştırılması. Beden Eğitimi ve Spor Bilimleri Dergisi, 4(3), 67-78.

Con, M. (2011). Takım ve Ferdi Sporcuların Kişilik Özellikleri İle Sportif Performansları Arasındaki İlişkinin Incelenmesi (pp. 35-36, Ondokuz Mayıs Üniversitesi Sağlık Bilimleri Enstitüsü Beden Eğitimi ve Spor Anabilim Dalı Doktora Tezi). 


\section{Macrothink}

Journal of Educational Issues

ISSN $2377-2263$

2020, Vol. 6, No. 2

Deniz, Ü., \& Kesicioğlu, O. (2012). Okul Öncesi Ögretmen Adaylarının Kișilik OOzelliklerinin Bazı Değişkenlerle Ilişkisinin Incelenmesi. Ahi Evran Üniversitesi Kırşehir Eğitim Fakültesi Dergisi, 13(2), 1-13.

Digitalage. (2020). Dijital Age. Retrieved from https://digitalage.com.tr/pandemi-sonrasidonem-hangi-sektorler-icin-dijital-firsatlar-getirecek

Dogu, O. (2017). Web Tabanl Uzaktan Egïtim ve Danışmanliğn Miyokard Enfarktüsü Geçirmis Bireylerin Tedaviye Uyumu ve Tyilik Durumuna Etkisi (p. 25, Istanbul Universitesi Sağlık Bilimleri Enstitüsü, Hemşirelik Esasları ABD Doktora Tezi).

Dorak, F., \& Tiryaki, Ş. (1991). Sporcularda Başarı ve Başarısızlı̆̆ın Nedenleri. Beden Eğitimi ve Spor Araştırmaları Dergisi, 2(5), 24-27.

Duda, J. L. (1989). Relationship Between Task and Ego Orientation and The Perceived Purpose of Sport Among High School Athletes. Journal of Sport and Exercise Psychology, 11(3), 318-335. https://doi.org/10.1123/jsep.11.3.318

Duda, J. L. (1992). Goal orientations and beliefs about the cause of sport success among elite skiers. The Sport Psychologist, 6, 334-343. https://doi.org/10.1123/tsp.6.4.334

Duda, J. L., \& White, S. A. (1992). Goal orientations and beliefs about the cause of sport success among elite skiers. The Sport Psychologist, 6, 334-343. https://doi.org/10.1123/ tsp.6.4.334

Erdogan, C. H. (2018). Beden Ë̆itimi Öğretmenlerinin Kişıllik Özellikleri Ahlaki Olgunluk Düzeylerinin ve Ö̌retmenlık Meslek Etiğ Hakkındaki Görü̈leri (pp. 56-54, Erciyes Üniversitesi, Sağlık Bilimleri Enstitüsü, Beden Eğitimi ve Spor Bilimleri A.B.D.).

Eygu, H., \& Karaman, S. (2013). Uzaktan Eğitim Öğrencilerinin Memnuniyet Algıları Uzerine Bir Araştırma. Sosyal Bilimler Dergisi, 3(1), 36-59.

Fox, K., Marios, G., Stuart, B., Joan, D., \& Amstrong, N. (1994). Children's Task and Ego Goal Profiles in Sport. British Journal of Education Psychology, 64(2), 253-261. https://doi.org/10.1111/j.2044-8279.1994.tb01100.x

Gill, D. L., Williams, L., \& Reifcteck, J. E. (2017). Psychological Dynamics of Sport and Exercise. Human Kinetics. Champaign, IL. https://doi.org/10.5040/9781492595779

Gunduz, N., Sevim, Y., \& Hazir, T. (2002). Elit Hentbolcularda Hazırlık Dönemi Öncesi, Hazırlık Dönemi Sonrası ve Müsabaka Dönemi Sonrası Dönemler Arasında Maksimal Laktik Asit ve AnaedrobikEşik Değişim Düzeyleri. Gazi Beden Ĕ̆itimi ve Spor Bilimleri Dergisi, $7(2), 3-10$.

Gursel, F., \& Koruc, Z. (2004). Hedef Belirlenen Engelli Olan ve Olmayan Öğrencilerde Antrenmanın Performans ve Duygusal Durumlar Üzerine Etkisi. Spor Bilimleri Dergisi, 15(3), 137-154. 
Haymana, B. (2019). Kitlesel Açık Çevrimiçi Derslerle Ilgili Yapılan Araștırmaların Incelenmesi: Tematık Içerik Analizi C,alışması (p. 9, Hacettepe Üniversitesi, Eğitim Bilimleri Enstitüsü, Bilgisayar ve Öğretim Teknolojileri Eğitimi A.B.D.).

İkizler, H. C. (1999). Sporda Başarının Psikolojisi. Alfa Yayınları.

Kalkavan, A., Özkara, A. B., \& Alemdağ, C. (2016). Akademisyenlerin Fiziksel Aktiviteye Katılım Düzeyleri ve Obezite Durumlarının İncelenmesi. International Journal of Sport Culture and Science, 4(1), 329-339. https://doi.org/10.14486/IntJSCS561

Kalkavan, A., Pınar, S., Kılınç, F., \& Yüksel, O. (2005). Basketbolcu Çocukların Fiziksel Yapılarının, Bazı Fizyolojik Ve Biyomotorik Özellikler Üzerine Etkisinin Araştırılması. Sağlık Bilimleri Dergisi, 14(2), 111-119.

Karanci, N., Dirik, G., \& Yorulmaz, O. (2007). Eysenck Kişilik Anketi Gözden Geçirilmiş Kısaltılmış Formunun (EKA-GGK) Türkiye'de Geçerlik ve Güvenirlik Çalışması. Türk Psikiyatri Dergisi, 18(3).

Kavussanu, M., \& Ntoumanis, N. (2007). Participation in Sport and Moral Functioning: Does Ego Orientation Mediate Their Relationship? Journal of Sport and Exercise Psychology, 25(4), 501-518. https://doi.org/10.1123/jsep.25.4.501

Kaynar, Ö., Seyhan, S., \& Bilici, M. (2018). Güreşçilerde Sportif Başarıyı Olumsuz Etkileyen Faktörlerin İncelenmesi. Beden Ĕ̆itimi ve Spor Bilimleri Dergisi, 20(1), 54-59.

Koknel, O. (1997). Kaygıdan Mutluluğa Kişilik. İstanbul: Altın Kitaplar.

Kostuk, K. J., Willoughby, K., \& Saedt, A. P. (2001). Modelling Curling as a Markov Process. European Journal of Operational Research, 133(3), 557-565. https://doi.org/10.1016/S03772217(00)00202-2

Marchant, D., \& Petah, G. (2004). Ethical Considerations in Treating Borderline Personality in Sport: A Case Example. The Sport Psychologist, 18(3), 317-323. https://doi.org/10.1123/ tsp.18.3.317

Moran, A. P. (2005). Sport and Exercise Psychology. Londra.

Oz, R. (2007). Internet Destekli Isıtma-Havalandırma Dersi Ögretimi (p. 5, Atatürk Universitesi Fen Bilimleri Enstitüsü, Doktora Tezi, Makine Mühendisliği Anabilim Dalı).

Ozbay, G., \& Oncu, E. (2012). Antrenörlerin Etik Dışı Davranışları İle İlgili Sporcu Algııı Ölçeğinin Geliştirilmesi. SPORMETRE Beden Egĭtimi ve Spor Bilimleri Dergisi, 2, 67-75. https://doi.org/10.1501/Sporm_0000000222

Ozçelik, I. Y. (2012). Elit Bayan Hentbolcularda Zihinsel Antrenmanın Yarıșma Kaygısı Ve Maç Performansina Etkisi (Ondokuz Mayıs Universitesi Sağlık Bilimleri Enstitüsü Beden Eguitimi ve Spor Anabilim Dalı Doktora Tezi).

Ozen, U., \& Eygu, H. (2010). Spor Psikolojisi ve Türkiye'de ki Futbol Hakemlerinin Hakemlik Psikolojileri Bir Araştırma. Uluslararası Spor Araştırmaları Dergisi, 2(1), 27-28. 


\section{Macrothink}

Journal of Educational Issues

ISSN 2377-2263

2020, Vol. 6, No. 2

Ozsarı, A., \& Cetin, M. Ç. (2019). Amatör Futbolcuların Görev ve Ego Yönelimlerinin Çeşitli Değişkenler Açısından Incelenmesi. Uluslararası Güncel Egĭtim Araştırmaları Dergisi, 5(2), 99-109.

Oztürk, O., \& Ulusahin, A. (2018). Ruh Sağlı̆̆l ve Bozuklukları (Cilt 4). Ankara: Nobel Tip Kitapevleri.

Park, S. G., \& Lee, S. (2013). Curling Analysis Based on the Possession of the Last Stone Per End. Procedia Engineering (6th Asia-Pacific Congress on Sports Technology), 60, 391-396. https://doi.org/10.1016/j.proeng.2013.07.028

Pol, P. K. C., \& Kavussanu, M. (2012). Achievement Motivation Across Training and Competition In Individual and Team Sports. Sport, Exercise and Performance Psychology, 1(2), 91-105. https://doi.org/10.1037/a0025967

Puspitari, K. A. (2007). Student Assessment Policy and Practice in Asian Distance Education. Pandora Distance Education Guidebook (p. 35).

Sercek, S., Karakas, A., \& Avci, Y. (2017). Otelcilik Ve Turizm Meslek Lisesi Öğretmenlerinin Kültürel Sermaye Yeterlik Düzeyleri İle Öz-Yeterlik Düzeyleri Arasındaki İlişki. Uluslararası Akademik Bakış Dergisi, 64, 562-572.

T.R. Ministry of Interior. (2020). Retrieved from https://www.icisleri.gov.tr/81-il-valiliginekoronavirus-tedbirleri-konulu-ek-genelge-gonderildi

Terkesli, R., \& Gul, Z. (2011). Sanal Sınıf Uygulamalarının Mesleki Gelişime Katkısının Değerlendirilmesi: Emniyet Genel Müdürlüğ̈̈ Orneği. Polis Bilimleri Dergisi, 13(4), 153-186.

Toros, T. (2002). Genç Basketbolcuların Oyunda Kalma Süreleri İle Hedef Perspektif Yaklaşımı, Yaşam Doyumu ve Algılanan Motivasyonel İklim Arasındaki İlişki. Spor Bilimleri Dergisi, 13(3), 24-36.

Toros, T. (2004). Sporda Görev ve Ego Yönelim Ölçeği (SGEYÖ)'nin Türk Sporcuları İçin Güvenirlik ve Geçerlilik Çalışması. Hacettepe Üniversitesi Spor Bilimleri Dergisi, 15(3), 155-166.

Toy, A. B. (2015). Serbest ve Grekoromen Stil Güreşçilerin Hedef Yönelimi ve Yaşam Doyumu İlişkisi (pp. 120-132, Hitit Üniversitesi, Sosyal Bilimler Enstitüsü, Beden Eğitimi ve Spor A.B.D, Yüksek Lisans Tezi).

Türkay, O., Korkutata, A., Şengül, S., \& Solmaz, S. (2005). Animasyon Hizmetlerinin Rekabet Gücüne Katkısı: Otel Işletmelerinde Katılımcı ve Pazar Yönlü Orgüt Kültürünün Etkileri Bağlamında Bir Araştırma. Bartın Üniversitesi İ.İ.B.F. Dergisi, 6(12), 80-102.

Turkey Football Federation. (2020). Retrieved from https://www.tff.org/Resources/Futbol GelisimBulteni/2/files/assets/basic-html/page5.html

Turkish Curling Federation. (2020). Retrieved from http://www.curling.gov.tr/detaylar/ 374/haber 
Turkish Volleyball Fedariton. (2018). Nisan 2020 Tarihinde Voleybolda Dayanıklllık Antrenmant. Retrieved from http://www.tvf.org.tr/wp-content/uploads/2018/08/ust_duzey_ antrenman_planlamasi-1.pdf

Usta, İ. (2015). Açıögřretim Fakuiltesi Sosyal Bilimler Onilisans Programının Değerlendirllmesi ve Geliștirilmesine Yönelik Oneriler (p. 4, Uzaktan Eğitim Anabilim Dalı Anadolu Universitesi Sosyal Bilimler Enstitüsü Doktora Tezi).

Uyar, M. (1997). Ö̇el Yabancı Dil Kursları Ornegïnde Video Destekli Almanca Ö̆retimine Eleștirel Bir Bakıș (p. 28, Yayımlanmamış Doktora Tezi).

Vealey, R. S. (2002). Personality and Sport Behavior. Advances in Sport Psychology, 5(1), 43-74.

Weiss, M. R., \& Ferrer-Caja, E. (2002). Motivational Orientations and Sport Behavior. Advances in Sport Psychology (Human Kinetics), 101-170.

WHO. (2020). Retrieved from https://www.who.int/dg/speeches/detail/who-director-generals-opening-remarks-at-the-media-briefing-on-covid-19---11-march-2020

Yigit, S., Dalbudak, İ., Mihriay, M., \& Gürkan, A. (2016). Examining Decision Making Level of Wrestlers in Terms of Some Variable. International Journal of Environmental and Science Education, 11(10), 3277-3284.

Yildız, R., Sünbül, M., \& Koç, H. (2002). Ö̆řetim Teknolojileri ve Materyal Geliștirme. Ankara, Turkey.

Yilmaz, V., Koruc, Z., Kocaeski, S., \& Arsan, N. (2019). Reasons of Sport Dropout for Children (p. 231). Uluslararası Spor Bilimleri Kongresi, Bildiri Kitabı.

Yorulmazlar, M. (2020). Müsabakaya Nasıl Hazllranılır? Retrieved from https://dostbeykoz. com/antrenor-musabakaya-nasil-hazirlanmalidir

\section{Copyright Disclaimer}

Copyright for this article is retained by the author(s), with first publication rights granted to the journal.

This is an open-access article distributed under the terms and conditions of the Creative Commons Attribution license (http://creativecommons.org/licenses/by/3.0/). 